\title{
INTERFERENSI ANTARA BAHASA ARAB DENGAN BAHASA MADURA \\ (Studi Kasus Pada Mahasiswa Prodi Pendidikan Bahasa Arab STAI Syaichona Moh. Cholil Bangkalan
}

\author{
Oleh: \\ Humaidi $^{1}$ \\ Email: tafakkursaatan@gmail.com
}

\begin{abstract}
In the aspect of social life, the function of language is traditionally as a verbal medium and also as a communication tool to convey thoughts of ideas and concepts, If in a society it consists of various regions with different language uses, language contacts and language interference will arisebetween the first language and the second language, that's why the researchers chose the title of interference that occurs between the languages first language (Madurans language) with the second language (Arabic language). In this research there are two formulations of the problem studied, the first is how is the form of interference used by students of syaichona cholil state, the second is how to speak the correct pronunciation of Arabic after interference. The formulation are intended to find out the various forms of interference that are often used and to provide knowledge on how to pronounce the correct language. This research uses descriptive qualitative research with the method of collecting data through three types, interviews, observation, and documentation with using the miles analysis model.The results of this research concluded that the occurrence of phonological and morphological interference was categorized into three typesfirst, elemental interference, interference is which occurs because of the inclusion of the morphological elements of the Madurans language into Arabic-like morphology, affixesthe example of the word astaghfirullah becomes poralla and syaitan becomes satan and others. Second, the interference pattern is morphological interference in the form of the use of the Madura language morphological process patterns in the formation of Arabic words the example

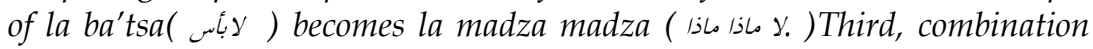
interference is the occurrence of elemental interference and interference patterns in one sentence like the word قلب قلب (be careful).
\end{abstract}

Key words: interference, Arabic language, madurans language

${ }^{1}$ Dosen Prodi Pendidikan Bahasa Arab STAI Syaichona Moh. Cholil Bangkalan 


\section{Pendahuluan}

Komunikasi merupakan media seseorang untuk menyampaikan keinginannya. Komunikasi memerlukan banyak ide, gagasan, isi dan sebagainya. Media yang vital akan keberlangsungannya komunikasi tersebuat adalah bahasa, maka dari itu peran bahasa yang paling utama salah satunya sebagai sarana komunikasi. Setiap masyarakat selalu terlibat dalam kontak bahasa, baik berperan sebagai ta'biriyah/komunikator (pembicara, penulis ) maupun sebagai istikbaliyah/ komunikan (penerima: pembaca, pendengar, penyimak) (Sumarlam, 2005:1).

Bahasa Madura termasuk bagian dari bahasa nusantara dan bagian dari rumpun bahasa austronesia yang ada di dunia. Secara histografis Bahasa Madura memiliki sejarah yang panjang, area penggunaan yang meluas dan jumlah penutur yang banyak. Bahasa Madura digunakan di beberapa wilayah di Indonesia, terutama di daerah Jawa Timur seperti: Bondowoso, Jember, Pasuruan, Malang, Probolinggo dan daerah Madura sendiri serta masih banyak lainnya. Menurut sudut pandang kehidupan manusia, bahasa selalu digunakan secara khas dan memiliki aturan tersendiri. Maka dari itu, banyak dijumpai kesamaan bahasa dalam kehidupan manusia, bahkan bisa dikatakan tidak terhingga, antara bahasa satu dengan yang lainnya. Meski demikian, terdapat banyak juga perbedaan antara satu bahasa dengan bahasa lainnya.

Bahasa merupakan salah satu media interaksi antara sesama manusia. Dalam aspek kehidupan bermasyarakat, fungsi bahasa secara tradisional sebagai media verbal yang digunakan oleh masyarakat untuk berkomunikasi. Akan tetapi, tidak hanya semata-mata sebagai alat komunikasi melainkan juga secara sosiolinguistik konsep bahasa itu sebagai media untuk menyampaikan pikiran ide, gagasan, dan lain-lain. (Abdul Chaer, 2004:15). Jika dalam suatu masyarakat terdiri dari berbagai daerah dan penguasaan bahasa yang berbeda-beda maka akan timbul kontak bahasa dan interfrensi bahasa, antara bahasa ibu dengan bahasa kedua, lebih-lebih jika dalam suatu kelompok masyarakat itu merupakan masyarakat multilingual, maka akan terjadi percampuran bahasa atau dalam istilah linguistik disebut campur kode, alih kode, dan interferensi. 
Dalam penelitian ini, mengkaji interferensi yang terjadi pada mahasiswa Pendidikan Bahasa Arab STAI Syaichona Moh. Cholil Bangkalan, data-data yang ditampilkan adalah bentuk-bentuk interferensi dari Bahasa Madura ke dalam Bahasa Arab. Bentuk interferensi dipengaruhi oleh penguasaan yang dimiliki oleh mahasiswa STAI Syaichona Moh. Cholil ketika mereka berkomunikasi. Ketika penutur berada dalam konteks domain situasi yang sesuai dengan tuntutan makna dan konteks.

\section{Metode Penelitian}

Penelitian ini menggunakan jenis penelitian deskriptif kualitatif, yaitu penelitian yang berupaya mendeskripsikan data-data temuan di lapangan, yang secara umum ialah metode pengkajian penelitian terhadap suatu masalah yang tidak didesain menggunakan prosedur-prosedur statistic (Edi Subroto, 1992: 5). Dalam penelitian ini berupaya untuk mendeskripsikan data-data kebahasaan yang terkait dengan interferensi Bahasa Madura ke dalam Bahasa Arab. Lokasi penelitian adalah kampus STAI Syaichona Moh.Cholil Bangkalan tepatnya pada prodi PBA. Lokasi ini dipilih karena prodi PBA merupakan kelas yang paling aktif dalam berbahasa Arab baik dalam kegiatan belajar mengajar di kelas maupun kegianta ekstra kebahasaan di luar perkuliahan seperti IRFA' sehingga banyak terjadi kotak bahasa yang secara spontan terjadilah interferensi satu sama lain dari Bahasa Madura terhadap Bahasa Arab, hal itu sangat dibutuhkan dalam mengumpulkan data-data yang diutamakan dalam penelitian ini.

Adapun data dalam penelitian ini berupa data lisan. Data lisan sebagai data utama yang digunakan dalam penelitian ini. Data lisan merupkan data yang berupa bahasa dari semua aktifitas kebahasaan yang mengandung interferensi dan macam-macamnya. Data ini berupa fenomena kebahasaan dengan segala aspek penutur pengguna bahasa yang diteliti secara alami (secara real). Sumber data pada penelitian ini berupa data kualitatif yang berasal dari informan terpilih sebagai pengguna bahasa dalam berkomunikasi di dalam kelas maupun di luar kelas. Adapun kriteria informan ialah: mahasiswa STAI Syaichona Moh.Cholil 
Bangkalan baik yang tinggal di pesantren maupun di luar pesantren, penutur Bahasa Madura, memiliki alat ucap yang baik bersedia memberi informasi kebahasaan secara jujur serta alamiah. Teknik pengupulan data dalam penelitian ini menggunkan tiga metode yaitu: observasi, wawancara, dan dokumentasi.

Pertama, observasi merupakan metode pengumpulan data dengan cara mengamati objek penelitian baik secara langsug maupun tidak langsung. ${ }^{2}$ Dalam penelitian ini peneliti mengamati proses belajar mengajar baik didalam kelas saat jam pelajaran berlangsung maupun di luar jam pembelajaran seperti kegiatan kebahasaan IRFA', diharapkan mampu mengungkap gejala fenomena kebahasaaan sebanyak mungkin terkait dengan bentuk interferensi. Kedua, wawancara yang digunakan dalam penelitian ini menggunakan wawancara tidak terstruktur dengan konsep pertanyaan yang diajukan terkait dengan penyebab terjadinya interferensi bahasa yang sesuai dengan rumusan masalah yaang diteliti, responden wawancara yaitu dengan mahasiswa dan dosen pengajar materi kuliah kebahasaan. Yang ketiga, ialah teknik dokumentasi yaitu teknik pengumpulan dataanya dari beberapa dokumen siswa seperti buku catatan dan tugas tugas, majalah serta hal hal yang berkaitan dengan tujuan penelitian ini. ${ }^{3}$

Dalam penelitian ini dilakukan analisis secara terus menerus sampai datanya jenuh dan dilakukan sejak sebelum memasuki lapangan yaitu sejak awal pengumpulan data, ${ }^{4}$ pada saat wawancara peneliti sudah melakukan analisis terhadap jawaban yang diwawancarai. Dalam penelitian ini analisis datanya menggunakan analisis data diskriptif model Miles dan Hubberman yaitu melalui data reduction, data display dan verification. 5 Tahapan analisis data, pertama yaitu reduksi data artinya temuan kebahasaan di lapangan yang terkait dengan interferensi

\footnotetext{
${ }^{2}$ Yatim riyanto, metode penelitian pendidikan, (Surabaya:Penerbit SIC, 2001) hlm.96

${ }^{3}$ Suharsimi Arikunto, prosedur penelitian; Suatu Pendekatan Praktik (Jakarta: PT. Renika Cipta, 1993), hlm.202.

${ }^{4}$ Matthew B.Mils dan A Michael Huberman, Analisis Data Kualitatif, ter, Tjetjep Rohendi Rohidi, (Jakarta: UI Press, 1992), hlm. 16

${ }^{5}$ Sugiyono, Metode Penelitian Pendidikan, (Bandung: Alfabeta, 2013), hlm.337.
} 
dirangkum, dipilah hal-hal yang pokok, difokuskan pada hal yang penting yaitu tentang interferensi, serta membuang yang tidak penting. Dengan mereduksi data akan memberikan gambaran yang jelas mengenai penelitian di lapangan yang berkaitan dengan interferensi fonologi dan morfologi dilapangan. Kedua, yaitu data display (menyajikan data) yaitu data diurai dalam bentuk uraian singkat, bagan hubungan antar kategori. Tahapan analisis yang ketiga, yaitu verification artinya menarik kesimpulan di dalam data temuan sehingga sehingga bisa menjawab rumusan masalah yang telah dirumuskan di awal dengan membaca keseluruhan yang dianggap mengalami interferensi kemudian menganalisisnya serta menyimpulkannya.

\section{Bentuk Interfrensi Fonologi antara Bahasa Arab dengan Bahasa Madura}

\begin{tabular}{|c|c|}
\hline $\begin{array}{c}\text { Bentuk Interferensi/Kesalahan } \\
\text { Fonologi (Bahasa Madura) }\end{array}$ & $\begin{array}{c}\text { Bentuk Fonologi/Pengucapan } \\
\text { yang Benar (Bahasa Arab) }\end{array}$ \\
\hline Ellam, Emmim, Ennun & Lam, min, nun \\
\hline Astagfirullahalajim & Astaghfirlah \\
\hline Maurip & Maghrib \\
\hline Sobbu & Subuh \\
\hline Setan & Syaiton \\
\hline Ketab & Kitab \\
\hline Arobiyeh & Arabiyah \\
\hline Ebbe' & Ba' \\
\hline Etta' & Ta' \\
\hline Jaman & Zaman \\
\hline Essen & Sen \\
\hline Zuhur & Dluhur \\
\hline Broka & Barokah \\
\hline Seinab & Zainab \\
\hline Kum salam & Wa'alaikum salam \\
\hline Mubazir & Mubadir \\
\hline Slasah & Tsalasah \\
\hline Alla & Allah \\
\hline Poralla & Astaghfirlah \\
\hline Msa'alla & Masya'Allah \\
\hline &
\end{tabular}




\section{Analisis Interferensi Fonologi}

Interferensi fonologi berupa pengurangan, penambahan huruf dalam pembentukan kata atau huruf. ${ }^{6}$ Atau dengan kata lain interferensi fonologi itu terjadi bilamana penutur menyisipkan bunyi-bunyi bahasa lain atau dalam penelitian ini Bahasa Madura. Data di atas Bahasa Arab terserap afiks Bahasa Madura sehingga terjadilah interferensi fonologi dalam bahasa tersebut. Salah satu contoh adalah orang Madura dalam menuturkan huruf ن، لام، ب dalam Bahasa Madura cenderung diberi imbuhan yang berasal dari Bahasa Madura sehingga menjadi "ennun, ellam, $e b b a$ " yang seharusnya penutur mengucapkan "nun, lam, $b a^{\prime}$ " tanpa adanya imbuhan di depannya. Dari sini terjadilah interferensi fonologi dalam percakapan mereka. Data di atas banyak peneliti temukan tidak hanya di jam perkuliahan berlangsung, melainkan juga di luar jam perkuliahan dengan ditemukannya suara di telinga kemudian ditiru dan dibiasakan sehingga bagi yang tidak mempunyai kesadaran akan penyimpangan kesalahan itu akhirnya terjadi pembiasaan yang dianggap benar. Data-data di atas yang banyak mengalami interferansi adalah dalam segi pengucapan huruf abjad Arab, tidak sedikit orang Madura dalam mengucapkan bahasa kedua tersisipi afik-afiks bahasa ibu, sehingga terjadilah interferensi Bahasa Madura terhadap Bahasa Arab yang nampak ketika diucapkan. Data-data temuan di atas juga banyak terjadi pada orang yang tidak mempelajari Bahasa Arab saja akan tetapi juga umumnya orang Madura, penyebabnya ialah adanya kemudahan dalam pengucapan kata-kata tersebut serta pembiasaanya dalam bertutur kata satu sama lain.

${ }^{6}$ Abd. Chaer 
Bentuk Interfrensi Morfologi Antara Bahasa Arab dengan Bahasa Madura

\begin{tabular}{|c|c|}
\hline $\begin{array}{l}\text { Bentuk interferensi/kesalahan } \\
\text { morfologi (Bahasa Madura) }\end{array}$ & $\begin{array}{l}\text { Bentuk morfologi/pengucapan } \\
\text { yang benar (Bahasa Arab) }\end{array}$ \\
\hline واحد مرة & مرة واحد \\
\hline قلب قلب & مهلا مهلا \\
\hline ل الا ماذا ماذا & 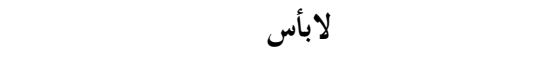 \\
\hline لا لعب لعب & ل ل ل ل ل لعب \\
\hline انت تعمل ماذا & 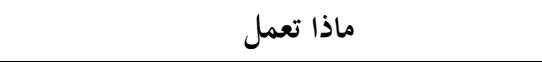 \\
\hline جمبل جميل & جميل جدا \\
\hline دفتر هذا جديد & هذا الدفتر جديد \\
\hline كرر واحد مرة & كرر مرة واحدة \\
\hline ماذا قال انت & ماذا تقول \\
\hline لا حياء حياء & لا ل احياء \\
\hline تقدم واحدا واحدا & تقدم واحدا بعد واحد \\
\hline 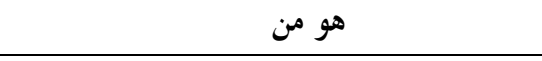 & 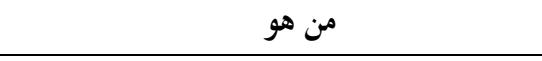 \\
\hline النار مات & مضسئ النار \\
\hline حياء حياء & 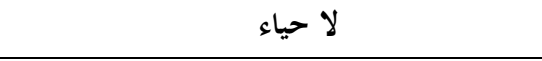 \\
\hline لע & ل \\
\hline اين-اين & اين \\
\hline متى-متى & 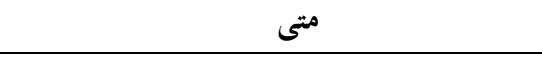 \\
\hline انت تجئ مع من & مع من أنت تجئ؟ \\
\hline انا خلاص أكل & قد أكلت \\
\hline سلام جاء من ارض ظاهر & أهلا وسهلا بحضوركم من الحرمين \\
\hline اريد طريق طريق & اريد رحلة \\
\hline نفسي-نفسي & دون الاشتراك \\
\hline قليل-قليل & قليلا-فقليلا \\
\hline سواء-سواء & على السواء \\
\hline كثير قلم & اقلام - ام \\
\hline
\end{tabular}




\begin{tabular}{|c|c|}
\hline هذا الرجل جميل & هاذا تقراء \\
\hline
\end{tabular}

\section{Analisis Interfrensi Morfologi}

Berdasarkan data temuan di atas, interferensi morfologi terjadi dalam pembentukan suatu kata itu terserap afiks-afiks bahasa lain sehingga merubah terhadap penggunaaan bahasa itu sendiri, atau dengan kata lain yaitu penyimpangan kata atau struktur dari kata Bahasa Madura terhadap kata Bahasa Arab. Perhatikan percakapan data di bawah ini.

$$
\text { أحمد: ما حكم تكلم اللغة إندونيسي دوام الدراسي المحادثة؟ }
$$

محمد : لا ماذا ماذا

Contoh di atas percakapan antara Ahmad dan Muhammad terjadi

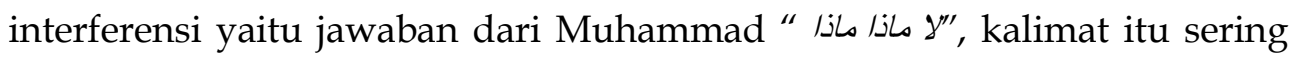
dituturkan oleh penutur yang bilingual (menguasai dua bahasa) yaitu Bahasa Arab dan Bahasa Madura, dalam konteks pemahaman kalimat itu bisa dipaham akan tetapi dalam konteks struktur morfologi/kosa kata itu terjadi interferensi dari Bahasa Madura terhadap Bahasa Arab, sebagaimana kita ketahui bahwa pemahaman interferensi adalah perubahan sistem atau suatu kata (kosa kata) dengan adanya kontak bahasa (persentuhan bahasa) dengan unsur bahasa lain yang diucapkan oleh penutur yang bilingual-bilingual disini mengacu terhadap penguasaan bahasa ibu (B1) dengan bahasa kedua (B2). Bentuk-bentuk tersebut merupkan penyimpangan dari morfologi Bahasa Arab, sebab kata itu meskipun bisa memberi pemahaman namun dalam Bahasa Arab merupakan sebuah kesalahan. Seharusnya jawaban si Ahmad dalam percakapan di atas sebagai berikut.

$$
\begin{aligned}
& \text { أحمد: ما حكم تكلم اللغة إندونيسي دوام الدراسي المحادثة؟ } \\
& \text { محمد : لابأس به }
\end{aligned}
$$


Kata yang benar untuk menjawab pertanyaan si Ahmad di atas ialah لابأس بـ. Berdasarkan data di atas bisa ditarik kesimpulan bahwa penyebab terjadinya interferensi morfologi ialah: pertama, karena kurang kontrol dalam menggunakan bahasa sehingga terselip afiks-afiks bahasa ibu. Kedua, karena kebiasaan dalam menggunakan sistem bahasa ibu. Ketiga karena adanya ketidaktahuan atau penguasaan bahasa oleh penutur.

\section{Kesimpulan}

Interferensi fonologi dari Bahasa Madura terhadap Bahasa Arab terjadi apabila penutur menyisipkan bunyi-bunyi bahasa lain/bahasa ibu (B1) terhadap bahasa kedua (B2), baik berupa imbuhan maupun perubahan dalam segi pengucapannya dan hal ini sering terjadi pada Bahasa Arab yang sudah sering diintegrasikan ke Bahasa Madura seperti kata astaughfirullah menjadi poralla dan syaiton menjadi setan dan lain-lain sebagaimana data di atas.

Sedangkan interferensi morfologi itu terjadi dalam pembentukan suatu kata terserap afiks-afiks bahasa lain sehingga merubah terhadap penggunaaan bahasa itu sendiri atau dengan kata lain yaitu penyimpangan kata atau struktur dari kata Bahasa Madura terhadap kata Bahasa Arab

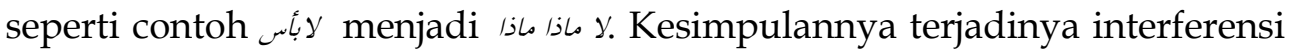
fonologi dan morfologi berdasarkan hasil penelitian ini dapat dikatagorikan ke dalam tiga jenis pertama, interferensi unsur yaitu interferensi yang terjadi karena masuknya unsur morfologi Bahasa Madura dalam morfologi Bahasa Arab (unsur seperti-bentuk, afiks). Kedua, interferensi pola yaitu interferensi morfologi berupa penggunaan pola proses morfologi Bahasa Madura dalam pembentukan kata Bahasa Arab. Ketiga, interferensi kombinasi yaitu terjadinya interferensi unsur dan interferensi pola pada satu kalimat. 


\section{DAFTAR PUSTAKA}

Arikunto, Suharsimi. 1993. Prosedur Penelitian: Suatu Pendekatan Praktik Jakarta: Renika Cipta.

Alwasilah, Chaedar. 1993. Pengantar Sosiologi Bahasa. Bandung: Penerbit Angkasa.

Chaer, Abdul. 2007. Linguistik Umum. Jakarta: Penerbit Rineka Cipta.

Miles, Matthew dan A Michael Huberman. 1992. Analisis Data Kualitatif. Ter, Tjetjep Rohendi Rohidi. Jakarta: UI Press.

Mills, Richard W. \& Mills, Jean. 1993. Bilingualism in Primary School. London: Routledge.

Moleong, Lexy J. 2005.Metodologi Penelitian Kualitatif. Bandung: Penerbit Rosda Karya.

Riyanto, Yatim. 2001. Metode Penelitian Pendidikan. Surabaya: Penerbit SIC.

Sudaryanto. 1993. Metode dan Aneka Teknik Analisis Bahasa. Yogyakarta: Duta Wacana University Press.

Sugiyono. 2013. Metode Penelitian Pendidikan. Bandung: Alfabeta. 